will be of interest mainly to those concerned with the planning of health care for large populations, both for its methodology and for its detailed consideration of many internationally important factors in such planning.

RICHARD KEATINGE, Registrar in Community Medicine, Department of Community Medicine, Wandsworth Health Authority,

London

\section{Psychology, Ethics and Change}

Edited by Susan Fairbairn and Gavin Fairbairn, 284 pages, London, £9.95, Routledge \& Kegan Paul, 1987

This book provides a welcome contribution to the examination of the moral values that underlie attempts to bring about psychological change. The editors see the book as an introduction leading to further debate about ethical issues. It is a multi-author volume, and the separate contributions deal with diverse issues. As such, it does not attempt to provide a coherent analysis or answers to questions, but allows each author to present his or her own preoccupations. Examples of some of the issues covered are: the appropriateness of a scientific basis for psychological theories; ethical concerns of different models of therapy; appropriate goals of therapy; behavioural medicine, and a challenge to psychologists to face their responsibilities in the face of nuclear threat.

Different preoccupations lead sometimes to mutually exclusive conclusions. One contributor argues for the provision of psychotherapy for everyone, whereas others consider the possibility of a 'disabling' effect of psychotherapy, when experts take over roles formerly performed by people themselves or by family and friends. There are arguments, wearyingly familiar to psychologists, from contributors who present their own theoretical model as the only ethical one. Some abuse is hurled at behaviour therapy and at family therapy. Practitioners in these two therapies, perhaps the most overtly manipulative, have for a long time grappled with ethical considerations relating to their practices. It is sometimes those whose control is more covert who may be much more complacent.

The chapters which have most relevance to medical ethics are those to do with psychological contributions to physical well-being. There is an excellent review by Rob Sanson-Fisher and Deborah Turnbull of the ethical issues involved in attempts to change the lifestyle of the community. They look at the ethics of health education and point out that giving information without providing the skills needed to change behaviour deprives a person of true autonomy to choose good health practices. They also point out the dangers of disregarding social contexts and working conditions in promoting individual responsibility for health. Also of interest are the issues involved in training medical students to be more effective communicators and considerations of autonomy and power in the doctor-patient relationship. There is a chapter by Annabel Broome on the benefits of psychological intervention in medical settings, and Richard Lindley questions the fairness in the distribution of health care and argues for psychotherapy being considered essential care.

A chapter on the ethical issues of psychotherapy for women, by Sue Llewelyn, concentrates on unethical behaviour which is especially important in relation to women, especially when the therapist is male. The occurrence of sexual abuse within the therapeutic relationship is examined as well as stereotyped attitudes towards women which may not be in their best interests. The author reminds us that all professionals who treat women with mental health problems need to consider what it is in the social context of women's lives that makes them disproportionately susceptible to mental health problems and to question whether the professional relationship doesn't reproduce some of these problems.

This book brings together people with a variety of viewpoints from within philosophy, psychology, psychotherapy and behavioural medicine. It provides some very lively and challenging reading and should be interesting to all those who are concerned with the moral dilemmas in psychological practice and also with the relationship between psychology and medicine. I would have liked to see some discussion of the ethical issues related to mental health and people from ethnic minorities but the book is a very stimulating introduction to a debate that has been surprisingly neglected in clinical psychology.

LORETTA SHOBEN, Principal Clinical Psychologist,
Psychology Department, Claybury Hospital, Woodford Green, Essex

\section{Pastoral Care and Ethical Issues In and Out of Work: A Pastoral Perspective}

Paul H Ballard, 192 pages, Edinburgh, £4.95, St Andrew Press, 1987

Paul Ballard trained for the Baptist ministry. His approach to work and employment as a pastoral concern is both sociological and theological. Indeed his book is one of large scope, even if it does not aspire to deal in any great depth with the variety of subjects it covers.

Ballard throws light on the recent history of employment in this country through many references to both Catholic and Protestant ethics and theologies of work. He also refers to modern political ideologies and economic theories.

Writing about the present, Ballard describes the trauma of losing one's job and unemployment. He analyses the degree of responsibility, engagement, work satisfaction and conflict entailed by different kinds of work. $\mathrm{He}$ examines the roles in society of both those who work and those who are unemployed. And he does so from the point of view of both the particular individual and those around him.

Viewing the pastoral care of both unemployed and employed against this wide background, the author takes the role of the counsellor to be largely educational. He does not see it solely as ministering to those in crisis but, instead more widely, as teaching people to make their own informed choices and to respond rationally and knowledgeably to their situations.

This book is both analytic and descriptive. It contains a detailed bibliography and, at the end of each chapter, a list of topics for discussion. It should provide stimulating reading for counsellor and counselled alike.

AGNETA SUTTON, The Linacre Centre, 60 Grove End Road, London NW8 9NH Medical Practice 
Bernard Knight, 341 pages, Edinburgh, £9.95, Churchill Livingstone, 1987

Medical students traditionally enjoy lectures on forensic medicine but experience shows they retain very little of the content. This is a book on clinical forensic medicine, not on forensic pathology, and it is thoroughly interesting even when dealing with set pieces such as the coroner system and asphyxia.

It deals with the law and the court system in Scotland and Ireland in a separate chapter; others should emulate this simplification.

The first third of the book covers ethical and legal duties - indeed the first few chapters are devoted to ethics (consent highlighted by the Gillick case) and negligence.

There is extended coverage of the Warnock Report in excellent chapters on sterilisation and artificial insemination, organ transplantation and embryo research.

The forensic medicine content is sensibly problem-based and covers all the classical 'bloodthirsty' areas under situation headings, viz examination of motor vehicle injuries, sudden natural death, wounding (including firearm injuries). Police surgeons should heed the warnings about death in custody, and the confused area of intoxication and head injury. There are useful asides on solvent abuse, the sexual asphyxias and the distinction between sudden infant death and cot death. There is repeated emphasis throughout the text on express informed consent, but perhaps the attitude towards life insurance reports provided by private medical attendants is not critical enough. Most people who sign the company's blanket consent form have no idea of the material the doctor may be going to reveal.

The book was produced before the GMC/BMA tangle about blood-testing for HIV antibodies, indeed HIV and hepatitis B do not appear in the index. The advent of DNA fingerprinting is likely to revolutionise identification disputes, paternity-testing cases and the production of trace evidence in sexual offences.

Inevitably the chapter on the battered child will need radical revision, post Butler-Schloss. Tabulation where appropriate, is excellent and linedrawings helpful: the rabbinical androgynous picture on page 127 reminded me powerfully of the Turin shroud.

An excellent book targeted at senior students, junior doctors and general practitioners, inviting them to think about behaviour itself, not just behaviour calculated to avoid official censure.

D G CRAIG,

Senior Forensic Medical Examiner Metropolitan Police and Senior Lecturer, Department of General Practice, Guy's Hospital Medical School, London

\section{Healing and Suffering - The Christian Paradox}

Paul Feider, 96 pages, London, £2.95, Darton, Longman \& Todd, 1988

Fr Paul Feider's book is a most welcome addition to the debate on Christianity and suffering. Although this work appears in Great Britain after first being published in America eight years ago, the topic is an ever-present and seeming contradition; something which is agonised over daily.

The book is subtitled 'The Christian Paradox' and so it must seem to those Christians who regularly minister to the sick. 'Why does God allow this to happen?' is a question we can face daily. Paul Feider here does us all a service by taking us back to the setting of the historical Jesus and the roots of Christian healing. Yet whilst keen on history he is not afraid to promote biblical textual criticism in a most acceptable way. He points out that Jesus is the master psychologist and psychotherapist in that He saw the need to liberate, to set free those who came presenting a physical illness, which then as now, so often had a spiritual need at its root. Jesus saw that healing was needed at the deep level of cause. He did not just deal with the effect.

Fr Feider is similarly most positive when dealing with the personality of Jesus and in this too he displays an intelligent use of biblical texts. He goes on to range over the value of suffering even the value of a personal weakness in keeping us humble before God (one can easily think of St. Paul's 'thorn in the flesh'). The idea of 'faith relationship' is introduced and I find this a most valuable concept, dealing as it does with the expression of Christ's Love made manifest in the sufferer or in the minister or both, to bring about healing. The best place for this faith relationship, Fr Paul tells us, is in a healing community where love and peace create the atmosphere for healing.
I'm sure this is well understood andT applied in the hospice situation, bu를. how many of us involved in busy majore? National Health Service (NHS) hospitals would feel that we were in healing atmosphere? Would it were so음 On this same point, the author speaks of the spiritual minister as being part of the 'healing team' - how constructive iס would be if this too were so! Maybe this is a feature of healing institutions ins America, but I wonder how many hospital chaplains really feel part of such a team, alongside their medica $\vec{\omega}$ colleagues?

There is much of importance in this easily read book especially so in the latter pages where Fr Feider tackles the $\vec{A}$ question of non-healing. How often wèt have to explain carefully that 'being healed' is not always to be equated with 'getting better' as the worldP understands this. Even the encounter with Jesus, we are reminded, does notand never has resulted in the removal of all suffering, but promotes liberation freedom from a guilt-ridden past and thereby allows true healing to take्ల place.

At the end of the book is car $\overrightarrow{0}$ autobiographical testimony in whelpo the author speaks frankly of the healing power of God's Love in his own Ifyeo This together with the chapter summaries and the question anfo discussion points suggested make the book the ideal vehicle for a parish hospital or fellowship study course. My church bookstall will certainly be stocking this very worthwhile? intelligent and reasonably price volume.

\section{MICHAEL WHAWELL \\ Vicar and Hospitaller' St Bartholomew's Hospital? London ECB}

\section{The Law Relating to the Health Care Professions}

P F C Bayliss, 207 pages, Kent, £19.50 soft cover, $£ 24.50$ hard cover,

Ravenswood Publications, 1987

The myriad statutes and bills relating te the health professions are understood at least in general terms, by those in active practice of their chosen branch $\frac{}{2}$ Doctors are aware of the existence of the Medical Act and its many up-dating and also of the role and constitution of the General Medical Council. Nurse who have the inclination, and the time 